\title{
Isolated Intramuscular Cysticercosis in Children: A Case Report
}

\author{
Çocuklarda İzole İntramusküler Sistiserkoz: Olgu Sunumu \\ (1) Krishna kumar H C, (1) Prashanth Satya Narayana, (1) Kalenahalli Jagadish Kumar \\ JSS Academy of Higher Education and Research, JSS Medical College, Mysore, India
}

Cite this article as: Kumar H C K, Narayana PS, Kumar KJ. Isolated Intramuscular Cysticercosis in Children: A Case

Report. Turkiye Parazitol Derg 2022;46(1):72-74.

\begin{abstract}
Human cysticercosis is an emerging infection caused by the larvae of Taenia solium (Cysticercus cellulosae). The most common sites for cysticercosis are the central nervous system, subcutaneous tissues, eyes, and muscles. Isolated intramuscular cysticercosis without brain involvement is rare and only a few reports are available in children. Here, we report two children with isolated intramuscular cysticercosis who presented with the swellings that were diagnosed by ultrasonography and fine-needle aspiration cytology. Both of them responded well to steroids and albendazole treatment, showing a complete resolution of the swelling. Keywords: Intramuscular cysticercosis, ultrasonography, fine needle aspiration cytology, albendazole
\end{abstract}

Öz

İnsan sistiserkozu, Taenia solium larvaları (Cysticercus cellulosae) nedeniyle ortaya çıkan bir enfeksiyondur. Sistiserkoz için en sık görülen bölgeler merkezi sinir sistemi, deri altı dokular, gözler ve kaslardır. Beyin tutulumu olmaksızın izole intramusküler sistiserkoz nadirdir ve çocuklarda sadece birkaç olgu raporu mevcuttur. Biz burada, şişliklerle başvuran, ultrasonografi ve ince iğne aspirasyon sitolojisi ile teşhis edilen izole intramusküler sistiserkozlu iki çocuğu sunuyoruz. Her ikisi de iyi seyretmiş, steroid ve albendazole iyi yanıt vererek şişlik tamamen çözülmüştür.

Anahtar Kelimeler: İntramusküler sistiserkoz, ultrasonografi, ince iğne aspirasyon sitolojisi, albendazol

\section{INTRODUCTION}

Throughout the globe, cysticercosis is the most common parasitic infection and the estimated prevalence is more than 50 millions (1). Cysticercosis, an emerging infection caused by encysted larvae of Taenia solium (2). It can involve any tissues and the most common sites are central nervous system, subcutaneous tissues, eyes, and muscles (2). In a study done by Ghimire et al. (1) out of 27 cases only 2 cases were below 15 years of age. Isolated intramuscular cysticercosis without brain involvement is rare and only few case reports are available in children (1). We are reporting 2 children presenting as intramuscular cysticercosis without brain involvement and both of them responded to albendazole.

\section{CASE REPORTS}

\section{Case 1}

A 12-year boy from muslim religion presented with a swelling of the right anterior axillary fold of about 2 months duration. The swelling was well defined, nodular, non-fluctuant, non-tender and measured about 2x2 cm clinically. The overlying skin appeared normal (Figure 1A). Child did not have cough, fever, or tuberculosis. There was no history of contact with tuberculosis. Other systems examination was unremarkable. Complete hemogram and stool microscopy were normal. Ultrasonography (USG) of the lesion showed a well-defined $1.1 \times 1.0 \mathrm{~cm}$ sized hyperechoic lesion with hypoechoic rim within the bulk of the pectoralis major muscle at the right anterior axillary fold (Figure 1B). Magnetic resonance 
imaging (MRI) brain was normal. Fine needle aspiration cytology (FNAC) smear shows histiocytes, epitheloid cells, many foreign type giant cells along with structures resembling cysticerus.

\section{Case 2}

A 10-year non-vegetarian boy from hindu religion presented with a swelling of the right middle forearm since one month. The swelling was well defined, non-fluctuant, non-tender and measured about $1 \mathrm{x} 2 \mathrm{~cm}$. The overlying skin appeared normal (Figure 2A). Child did not have cough, fever, or tuberculosis. There was no history of contact with tuberculosis. Other systems examination was unremarkable. Complete hemogram and stool microscopy were normal. Ultra sound revealed well defined lesion measuring $13.6 \times 6.8 \mathrm{~mm}$ in the intramuscular part of middle forearm. Cystic lesion measuring $6.8 \times 4 \mathrm{~mm}$ with an eccentric calcified nodule noted within the lesion (Figure 2B). MRI brain was normal. FNAC smear shows histiocytes, epitheloid cells, good number of eosinophils along with fragments of wispy acellular eosinophilic material of cysticerus present.

Both of them were started on $2 \mathrm{mg} / \mathrm{kg} /$ day of oral prednisolone and $15 \mathrm{mg} / \mathrm{kg} /$ day of oral Albendazole. Prednisolone was given for first 7 days and albendazole was given for 15 days. On followup the swellings disappeared.

\section{DISCUSSION}

In many developing countries of the world cysticercosis has become endemic and causing major public health problem (1). Eventhough the exact figures of cysticercosis are not known in India, occurrence is alarmingly high (3). In rural India, the seroprevalence of cysticercosis is $22.4 \%$ and it increases with age (3). Even in vegetarians, cysticercosis is equally common, probably due to faecal contamination of water and improperly washed uncooked food $(4,5)$. Due to religious restriction, muslims do not consume pork, however one of our child is a muslim boy (4). Probably he must have acquired through other means like contaminated uncooked food. In a study from India out of 15 patients seven were vegetarians (5). Children commonly suffer because of fomite infection $(1,2)$. Isolated intramuscular cysticercosis without involvement of the brain is rare and often present a difficult diagnostic challenge to the treating physician $(1,2,4,6)$. However, in both our cases MRI brain was performed and there was no involvement. There is wide spectrum of clinical presentations. It can be asymptomatic or can present with painful, tender swellings and this depends on the site, number and the associated inflammation of the cysts $(1,2)$. The most common presentation of soft tissue cysticercosis is

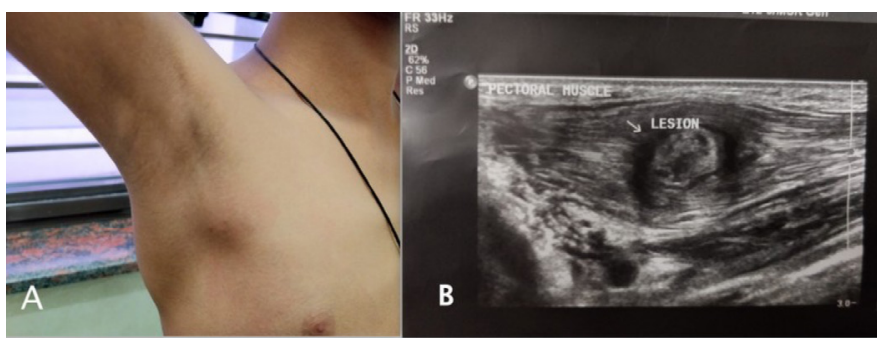

Figure 1. A) Well defined, nodular, swelling in the pectoralis major muscle, B) Sonography showing a well-defined 1.1x1.0 $\mathrm{cm}$ sized hyperechoic lesion with hypoechoic rim within the bulk of muscle lump in the upper limbs $(1,3)$. Involvement is more common seen in head, neck, trunk and upper extremity. Usually fever is absent (2). There was no relation between the symptom and size of the lesion in a study from Nepal (1). There are three types of clinical presentations of muscular cysticercosis: myalgic myopathic type; the nodular or mass like type; and the pseudohypertrophy type (2). Death of the cyst and leakage of fluid leading to inflammation leads to myalgic type of muscular cysticercosis. Cystic degeneration and intermittent leakage of fluid slowly over time causes a chronic inflammation; leads to collection of fluid around the cyst producing a mass which in turn causes nodular type or pseudotumor type of muscular cysticercosis (2). Both the cases belong to nodular type in our series. Out of 17 cases muscles of the upper extremities were involved in ten cases but none of them had pectoralis majour muscle involvement (1).

Living cysticerci escape immune recognition, therefore does not cause inflammation (2). So clinically it remains silent. But it can causes signs or symptoms depending upon the cyst location and size (2). Leakage of fluid from the cysts after the larval death, induces a vigorous acute inflammation. Therefore acute inflamation produce symptoms like local pain and myalgia depending on the anatomic location (2).

Differential diagnosis of intramuscular cysticercosis include intramuscular abscess, epidermoid cysts, neurofibromas, neuroma, lipomas, pyomyositis, pseudoganglia, myxoma, sarcoma, cold abscess or tuberculous lymphadenitis $(2,4,6,7)$. Clinically, cysticercosis was misdiagnosed as lipoma in 11 out of 27 cases in a study from Nepal (1).

High-resolution sonography is quick, cheap, non-invasive, nonionizing, easy to perform with minimum patient discomfort $(2,5)$. Cystic lesions can be effectively evaluated by sonography and this unique quality provide good chance with good accuracy to diagnose extra-cranial cysticercosis (8). On sonography intramuscular cysticercosis has the appearance of an eccentric echogenic scolex, which is a characteristic feature (2). Four types of intramuscular cysticercosis occur on sonography. The first type is due to death of the larva which leads to cysticercus cyst with the surrounding inflammatory mass. Second type occur because of leakage of fluid which causes is an irregular cyst with very minimal fluid on one side. The eccentric echogenic protrusion from the wall due to the scolex is not seen within the cyst. This kind of look on sonography may be due to escape of

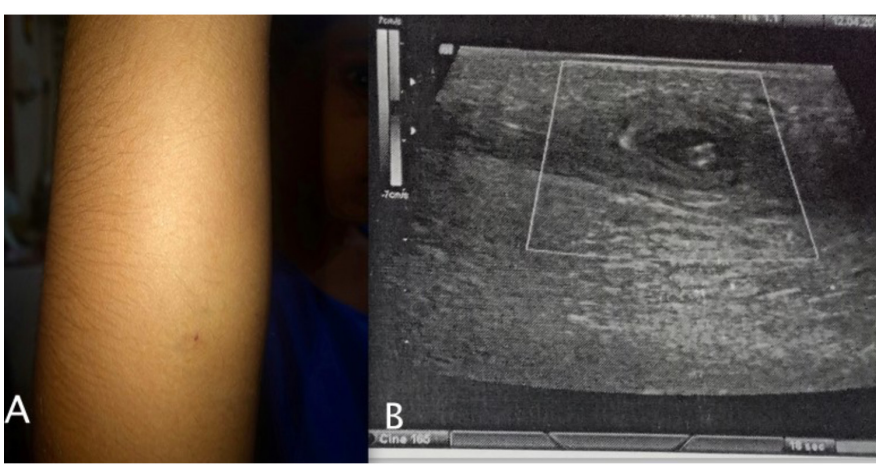

Figure 2. A) Swelling in the middle forearm since one month, B) Sonography showing well defined lesion measuring $13.6 \times 6.8$ $\mathrm{mm}$ in the muscle and cystic lesion measuring $6.8 \times 4 \mathrm{~mm}$ with an eccentric calcified nodule noted within the lesion 
scolex outside the cyst or due to partial collapse of the cyst. Third type occurs due to chronic inflammation around the cyst. In this there is typical cysticercus cyst containing the scolex, situated eccentrically along with large irregular collection of exudative fluid within the muscle which resemble intramuscular abscess. The characteristic feature in all these three patterns is that of the cysticercus itself. Cysticercus cyst visible as an oval or round welldefined lesion with an eccentric echogenic scolex in it. Type fouth is a calcified cyst which looks as multiple elliptical calcifications in the soft tissue (2). USG of first child showed a well-defined $1.1 \times 1.0 \mathrm{~cm}$ sized hyperechoic lesion with hypoechoic rim within the bulk of the pectoralis major probably of second type. Ultra sound of second case revealed well defined lesion containing cysticercus cyst with an eccentric calcified swelling noted within lesion probably of third type with calcification.

In a study by Naik et al. (5) the commonest ultrasound appearance of myocysticercosis was that of third type (an eccentrically situated typical cysticercus cyst with a scolex along with collection of exudative fluid within the muscle which resemble intramuscular abscess). The next common appearance was classical cysticercus cyst with a scolex within and surrounding mild edema without abscess. Irregular cysticercus cyst without scolex within along with surrounding minimal fluid on one side of the cyst due to leakage of fluid is the least common type (5).

In a study from Nepal sonography could suggest cysticercosis in 24 cases out of 27 cases (1).

To diagnose soft tissue cysticercosis, FNAC is a good diagnostic tool $(7,9)$. But as it is invasive method, cysticercosis can be diagnosed by imaging techniques $(7,10)$. FNAC of the swelling showed histocytes, epithelioid cells many foreign body giant cells along with few structures of cysticercus in our cases. Small broken parts of parenchyma and cuticle of larvae highly indicative of cysticercosis (1). Ghimire et al. (1) concluded that FNAC and histopathological assessment is advisable in the diagnosis muscular cysticercosis if there is diagnostic dilemma. Fineneedle aspiration cytology is a rapid, safe, cheap, and reliable investigation which may preclude the need biopsy and useful in reaching a preoperative diagnosis $(2,4)$.

Both children were treated with albendazole for 15 days along with prednisolone for a week. They responded well with respect to size and pain. Decision regarding the treatment depends on various factors like clinical features, site of involvement, number, stage, and size of cysts (2). Treatment choices include drugs, surgery or wait and watch (2). Both medical and surgical line of management have been found to be beneficial, therefore choice of treatment should be individualized (2).

\section{CONCLUSION}

Eventhough solitary myocysticercosis is rare in children, high index of suspicion should be kept in a child with an intramuscular swelling irrespective of the religion. High resolution sonography is useful non-invasive diagnostic modality to arrive at the diagnosis.

\section{* Ethics}

Informed Consent: Informed consent was obtained.

Peer-review: Internally peer-reviewed.

* Authorship Contributions

Concept: K.J.K., Design: K.J.K., Data Collection or Processing: K.K.H.C., P.S.N., Analysis or Interpretation: K.J.K., Literature Search: K.K.H.C., P.S.N., K.J.K., Writing: K.J.K.

Conflict of Interest: No conflict of interest was declared by the authors.

Financial Disclosure: The authors declared that this study received no financial support

\section{REFERENCES}

1. Ghimire PG, Ghimire P, Rana R. Spectrum of Typical and Atypical ClinicoHistopathological and Radiological Presentation of Soft Tissue and Muscular Cysticercosis in Mid-Western and Far-Western Region of Nepal. J Clin Diagn Res 2015; 9: EC01-3.

2. Meena D, Gupta M, Jain VK, Arya RK. Isolated intramuscular cysticercosis: Clinicopathological features, diagnosis and management - A review. J Clin Orthop Trauma 2016; 7(Suppl 2): 243-9.

3. Sinha S, Tiwari A, Sarin YK, Khurana N. Isolated soft tissue cysticercosis involving the trunk in children: report of 4 cases. APSP J Case Rep 2013; 4: 35 .

4. Jaiswal P, Yadav YK, Jaiswal S, Bhasker N. Isolated cysticercosis involving the anterior abdominal wall: a rare case report. J Parasit Dis 2017; 41: 578-9.

5. Naik D, Srinath M, Kumar A. Soft tissue cysticercosis - Ultrasonographic spectrum of the disease. Indian J Radiol Imaging 2011; 21: 60-2.

6. Dubey P, Chodankar R, Chawla L, Bhat T, Rani V. Isolated Forearm Swelling - A Rare Presentation of Soft Tissue Cysticercosis. Am J Case Rep 2014; 2: 243-6.

7. Kanhere S, Bhagat $\mathrm{M}$, Phadke V, George R. Isolated intramuscular cysticercosis: a case report. Malays J Med Sci 2015; 22: 65-8.

8. Ghonge NP, Mittal D. Evaluation of imaging patterns of extra-cranial cysticercosis in North India. Radiology of Infectious Diseases 2017; 4: 49-57.

9. Dhyani A, Anand A. Unusual Presentations of Soft Tissue Cysticercosis in Children Causing Diagnostic Dilemma: Report of Two Cases of Soft Tissue Cysticercosis National Journal of Laboratory Medicine 2016; 5 : MC01-3.

10. Sohoni CA. Isolated Cysticercosis Lump over Thigh in a Child. APSP J Case Rep 2015; 6: 21. 